\title{
Mesenchymal stromal cells therapy in radiation oncology regenerative medicine
}

\author{
Osama Muhammad Maria ${ }^{1,3,4}$, Nicoletta Eliopoulos ${ }^{2,4}$ and Thierry Muanza ${ }^{1,3,4,5 *}$ \\ ${ }^{1}$ Experimental Medicine Department, Faculty of Medicine, McGill University, Montreal, Quebec, Canada \\ ${ }^{2}$ Surgery Department, Faculty of Medicine, McGill University, Montreal, Quebec, Canada \\ ${ }^{3}$ Radiation Oncology Department, Jewish General Hospital, McGill University, Montreal, Quebec, Canada \\ ${ }^{4}$ Lady Davis Institute for Medical Research, Jewish General Hospital, McGill University, Montreal, Quebec, Canada \\ ${ }^{5}$ Oncology Department, McGill University, Montreal, Quebec, Canada
}

\begin{abstract}
Mesenchymal stromal cells (MSCs) are multipotent somatic cells resident in many tissues and organs. They have specific characteristics that distinguish them from other cell types. They are self-renewing cells with multi-lineage differentiation potential. In addition, they possess anti-inflammatory and immunomodulatory properties. Studies have shown that they could be used as vehicles to deliver certain therapeutic gene products as well. These cells possess secretory capabilities of certain cytokines and growth factors that mediate various paracrine effects. They increase the secretion of the anti-inflammatory interleukin-10 (IL-10) together with lowering the availabilities of tumor necrosis factor-alpha (TNF- $\alpha$ ), interferon-gamma (INF- $\gamma$ ), and interleukin -1-beta (IL-1 $\beta$ ) by signaling to the immune system elements, e.g. dendritic cells, T-cells, B-cells, and natural Killer cells (NK cells). Recently, studies have investigated such anti-inflammatory properties of MSCs in the repair of radiation-induced normal tissue injury, also called radiation oncology regenerative medicine (RORM), supported by the recently known MSCs radiation resistance potential. In this review, we summarize MSCs radio-resistant mechanisms, anti-inflammatory properties, and their application in RORM with special attention to adipose tissue-derived MSCs (aMSCs).
\end{abstract}

\begin{abstract}
Abbreviations: aMSCs: Adipose tissue-derived mesenchymal stromal cells, ATM: Ataxia telangiectasia mutated protein, b-FGF: Basic fibroblast growth factor, Chk: Check point cell cycle kinase, DSB: Double stranded DNA breaks, HGF: Hepatocyte growth factor, HR: Homologous recombination,HSCs: Hematopoietic stem cells, IL-10: Interleukine-10, IL-1 $\beta$ : Interleukine-1-beta, IDO: Indoleamine 2,3-dioxygenase, INF- $\gamma$ : Interferon-gamma, MSCs: Mesenchymal stromal cells, NHEJ: Non-homologous end-joining, NK: Natural killer cells, NO: Nitric oxide, PGE2: Prostaglandin-E2, RORM: Radiation oncology regenerative medicine, TGF- $\beta$ : Tumor growth factor-beta, TNF-a: Tumor necrosis factor-alpha
\end{abstract}

\section{Introduction}

Mesenchymal stromal/Stem cells (MSCs) are multipotent somatic progenitor cells that have been isolated from different tissues, such as bone marrow, adipose tissue, muscles and skin [1-3]. They can be expanded ex-vivo to hundreds of million cells, maintaining their phenotype and characteristics, and used as therapies in different diseases [1-3]. Another property of these cells is their homing to the site of tissue injury, an ability that widens the choices for their route of administration $[2,4,5]$. In addition to their multi-lineage differentiation potential [6], these cells possess anti-inflammatory and immunomodulatory properties and paracrine effects that qualified them for regenerative medicine applications (Figure 1) [711]. Furthermore, MSCs could be genetically engineered and used as vehicles for delivering therapeutic gene products [12-14]. Studies in radiotherapy have shown that MSCs can be recruited to the radiation injury site where they secrete many cytokines and growth factors, e.g. prostaglandin-E2 (PGE2), nitric oxide (NO), hepatocyte growth factor (HGF), interleukin-10 (IL-10), tumor growth factor-beta (TGF- $\beta$ ), and indoleamine 2,3-dioxygenase (IDO) [15]. These soluble mediators inhibit the major components of the immune system and inflammation, e.g. dendritic cells, T-cells, B-cells, and natural killer cells (NK cells) [15]. The final result will be an increase in the secretion of the anti-inflammatory interleukin-10 (IL-10) together with lowering the availability of pro-inflammatory mediators and cytokines, e.g. tumor necrosis factor-alpha (TNF- $\alpha$ ), interferon-gamma (INF- $\gamma$ ), and interleukin -1-beta (IL-1 $\beta$ ) [15] (Figure 1).

\section{Mesenchymal stromal cells (MSCs) clinical trials in various disorders}

MSCs have been applied for various repairs, such as of arthritis [16], cardiac muscle [17,18], lung tissue [14], diabetes [19], skin [2023], skeletal tissue [24], and digestive tract tissue [12,25,26]. Table 1 shows 92 recent clinical trials for MSCs therapies in various disorders.

Correspondence to: Dr. Thierry Muanza, MD, MSc, FRCPC, Radiation Oncology Translational Research Lab, Department of Radiation Oncology, Jewish General Hospital and Lady Davis Institute Research Centre, McGill University, 3755 Côte-St.-Catherine Road, Suite G002, Montréal, Québec, Canada, H3T 1E2, Tel: +1 (514)-340-8288, Fax: + 1 (514)-340-7548, E-mail: tmuanza@yaoo.com

Key words: adipose tissue, anti-inflammatory, cell cycle, DNA repair, mesenchymal stromal cells, msc, normal tissue injury, radiation oncology regenerative medicine, radiation resistance

Received: June 05, 2016; Accepted: July 04, 2016; Published: July 07, 2016 


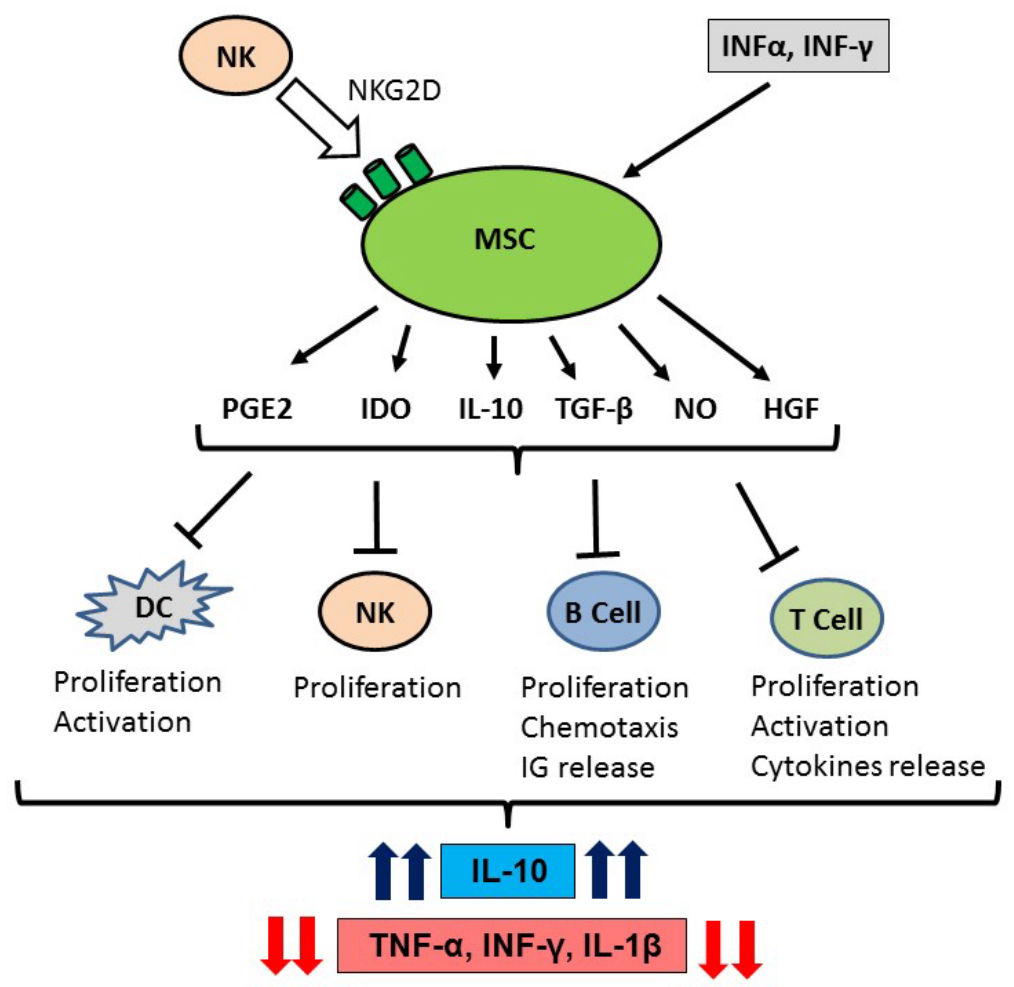

Figure 1. MSCs anti-inflammatory properties

MSCs recruited to the radiation injury site secrete many cytokines and growth factors, e.g. prostaglandin-E2 (PGE2), nitric oxide (NO), hepatocyte growth factor (HGF), interleukin-10 (IL-10), tumor growth factor-beta (TGF- $\beta$ ), and indoleamine 2,3-dioxygenase (IDO). These soluble mediators inhibit the major components of the immune system and inflammation, e.g. dendritic cells, T-cells, B-cells, and natural killer cells (NK cells). The final result will be an increase in the secretion of the anti-inflammatory interleukin-10 (IL-10) together with lowering

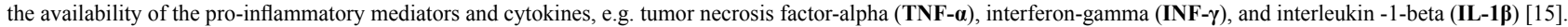

\section{MSCs radio-biological response}

The exposure of MSCs to ionizing radiation (IR) induces direct and indirect double stranded DNA breaks (DSB) which are detected by Poly (ADP-ribose) polymerase (PARP) and heterodimeric Ku protein complex (Ku70/80) sensor proteins [27,28]. At the DSB location, PARP started the signal amplification upon formation of the Mre11, RAD50, and NBS-1 protein complex which leads to recruitment and auto-phosphorylation of Ataxia Telangectasia mutated protein (ATM). Phosphorylated ATM (p-ATM) is a main station that leads to multiple downstream signals. P-ATM enhances the phosphorylation of histone $\mathrm{H} 2 \mathrm{X}$ (to $\gamma$-H2AX) and DNA-PK (to p-DNA-PK), phosphorylates P53 (a tumor suppressor regulatory protein), activates the cell cycle checkpoint effector protein kinases (Chk-1 and Chk-2), and prepares for cell cycle arrest (G2/M). In addition, the Chk1 activation is augmented by the replication stress-mediated ATR pathway (through replication protein A, RPA), while the Chk2 activation is enhanced directly through Ku70/80-mediated p-DNA-PK signaling [27,28]. Cell division cycle phosphatase (Cdc25) is crucial for removing the inhibitory phosphorylation on specific residues on the cyclin-dependent kinase (Cdk). Chk1 phosphorylates Cdc25 in the presence of DNA damage resulting in the inhibition of Cdc25 activity. Chk1 and Chk2 are main inhibitors of Cdc25A and Cdc25C resulting in Cdk/cyclin-mediated cell cycle arrest [29]. It has been suggested that DSB in MSCs are repaired by activation of both the homologous recombination (HR, during $S$ and G2 phases) and the non-homologous end-joining (NHEJ, during all cell cycle phases) DNA repair pathways [27,28,30]. Our recent study showed the activation of $\mathrm{HR}$ and NHEJ repair pathways in irradiated aMSCs [31]. In addition, p-ATM enhances the stabilization of the tumor suppressor regulatory protein and transcription factor P53 which up-regulates the expression and enhances the stabilization of the transcription factor and inhibitory regulatory protein $\mathrm{p} 21$, which potently inhibits Cdks which are needed for the G1/S transition leading to inhibition of the entry into $S$ phase [27].

The application of MSCs in radiation oncology regenerative medicine (RORM) was enhanced by their efficient radiation-induced DNA repair machinery and their relative radiation resistance [30-34]. Such radiation resistance was mediated by many mechanisms, e.g. the ATM phosphorylation, activation of cell cycle check points (G2/M arrest), and activation of single and double stranded DNA repair by both homologous and non-homologous recombination mechanisms and other pathways [30,31] (Figure 2). DSB resulting from the direct and indirect radiation injury stimulate the phosphorylation of ATM which is the proximal step for cell cycle check point's activation (G2/M arrest). In addition, the nuclear apoptotic factor P84 (P84/53E10 = the nuclear protein encoded by the N5 gene) is up regulated, which participates in the apoptotic response of the aMSCs. It has been documented that irradiated aMSCs showed p-ATM dependent and p-ATM independent (P84-mediated) G2/M arrest [31]. Phosphorylated histone-2AX $(\gamma-\mathrm{H} 2 \mathrm{AX})$ stimulated both the HR and the NHEJ of the dsDNA breaks and other repair mechanisms [35]. Rad-51 is considered one of the mandatory proteins for HR to occur. DNA-PK is the major protein in the NHEJ repair pathway. Studies have shown that both proteins (Rad-51 and DNA-PK) were up regulated in irradiated MSCs (Figure 2) [28,30,31]. 
Table 1. Mesenchymal Stromal cells (MSCs) clinical trials in various disorders as listed on www.ClinicalTrials.gov by the National Institute of Health (NIH) by Nov. 2015.

\begin{tabular}{|c|c|c|c|c|}
\hline NCT \# & Title & Conditions & Interventions & Last Verified \\
\hline NCT01589549 & $\begin{array}{l}\text { Mesenchymal Stromal Cells for Acute Graft Versus } \\
\text { Host Disease }\end{array}$ & Acute GVH Disease & Biological: Mesenchymal stromal cell therapy & Jun-15 \\
\hline NCT02057965 & $\begin{array}{l}\text { Mesenchymal Stromal Cell Therapy in Renal } \\
\text { Recipients }\end{array}$ & Renal Transplant Rejection|Fibrosis & Drug: Mesenchymal Stromal Cells & Mar-15 \\
\hline NCT02032446 & $\begin{array}{c}\text { Umbilical Cord Derived Mesenchymal Stromal Cells } \\
\text { For The Treatment of Severe Steroid-resistant Graft } \\
\text { Versus Host Disease }\end{array}$ & Hematologic Malignancies & $\begin{array}{l}\text { Biological: UMBILICAL CORD DERIVED } \\
\text { MESENCHYMAL STROMAL CELLS (UC-MSC) }\end{array}$ & Apr-15 \\
\hline NCT02012153 & $\begin{array}{l}\text { Mesenchymal Stromal Cells in Kidney Transplant } \\
\text { Recipients }\end{array}$ & Kidney Transplant Rejection & Biological: Mesenchymal Stromal Cells & Oct-15 \\
\hline NCT01090817 & $\begin{array}{c}\text { An Australian Study of Mesenchymal Stromal Cells } \\
\text { for Crohn's Disease }\end{array}$ & Crohn Disease & $\begin{array}{c}\text { Drug: Mesenchymal stromal cells (MSC) for } \\
\text { infusion }\end{array}$ & Jun-15 \\
\hline NCT00644410 & $\begin{array}{l}\text { Autologous Mesenchymal Stromal Cell Therapy in } \\
\text { Heart Failure }\end{array}$ & Congestive Heart Failure & $\begin{array}{c}\text { Biological: Mesenchymal stromal cell| } \\
\text { Biological: Saline }\end{array}$ & Mar-15 \\
\hline NCT01061099 & $\begin{array}{l}\text { Repeated Infusions of Mesenchymal Stromal Cells in } \\
\text { Children With Osteogenesis Imperfecta }\end{array}$ & $\begin{array}{l}\text { Osteogenesis Imperfecta Type II } \\
\text { Osteogenesis Imperfecta Type III }\end{array}$ & Biological: Mesenchymal Stromal Cells & Apr-15 \\
\hline NCT02150551 & $\begin{array}{c}\text { Safety and Tolerability Of Allogeneic Mesenchymal } \\
\text { Stromal Cells in Pediatric Inflammatory Bowel } \\
\text { Disease }\end{array}$ & Inflammatory Bowel Diseases & $\begin{array}{l}\text { Biological: Allogeneic bone marrow-derived } \\
\text { mesenchymal stromal cells }\end{array}$ & Sep-15 \\
\hline NCT01522716 & $\begin{array}{c}\text { Mesenchymal Stromal Cells as Treatment of Chronic } \\
\text { Graft-versus-host Disease }\end{array}$ & Graft-Versus-Host Disease & Biological: Mesenchymal stromal cells & Nov-15 \\
\hline NCT02323789 & $\begin{array}{c}\text { A Phase I/II Study Evaluating Allogeneic } \\
\text { Mesenchymal Stromal Cells in Adults With Recessive } \\
\text { Dystrophic Epidermolysis Bullosa }\end{array}$ & $\begin{array}{l}\text { Recessive Dystrophic Epidermolysis } \\
\text { Bullosa }\end{array}$ & Drug: Mesenchymal stromal cells & Dec-14 \\
\hline NCT02291770 & $\begin{array}{c}\text { Treatment of Chronic Graft-Versus-Host Disease } \\
\text { With Mesenchymal Stromal Cells }\end{array}$ & Chronic Graft-Versus-Host Disease & Biological: Mesenchymal Stromal Cells & Nov-14 \\
\hline NCT01764100 & $\begin{array}{l}\text { Mesenchymal Stromal Cells (MSCs) for the } \\
\text { Treatment of Graft Versus Host Disease (GVHD) }\end{array}$ & Graft vs Host Disease & Genetic: Mesenchymal stromal cells & Jan-13 \\
\hline NCT02230514 & $\begin{array}{l}\text { Mesenchymal Stromal Cells for the Treatment of } \\
\text { Non-union Fractures of Long Bones }\end{array}$ & Atrophic Nonunion of Fracture & $\begin{array}{l}\text { Drug: XCEL-MT-OSTEO-ALPHA|Other: } \\
\text { autologous iliac crest| Procedure: Surgery }\end{array}$ & Jul-15 \\
\hline NCT02215811 & $\begin{array}{c}\text { Treatment of Severe Acute Respiratory Distress } \\
\text { Syndrome With Allogeneic Bone Marrow-derived } \\
\text { Mesenchymal Stromal Cells }\end{array}$ & $\begin{array}{c}\text { Acute Respiratory Distress Syndrome, } \\
\text { Adult }\end{array}$ & Biological: Mesenchymal stromal cells & Aug-14 \\
\hline NCT01449032 & $\begin{array}{c}\text { Mesenchymal STROMAL CELL Therapy in Patients } \\
\text { With Chronic Myocardial Ischemia (My Stromal } \\
\text { Cell Trial) }\end{array}$ & Chronic Ischemic Heart Disease & Biological: MSC| Biological: Saline & Jun-14 \\
\hline NCT02580695 & $\begin{array}{l}\text { A Study to Assess Safety and Efficacy of Umbilical } \\
\text { Cord-derived Mesenchymal Stromal Cells in Knee } \\
\text { Osteoarthritis }\end{array}$ & Osteoarthritis & $\begin{array}{c}\text { Biological: umbilical-cord mesenchymal stromal } \\
\text { cells| Drug: Hyaluronic Acid }\end{array}$ & Oct-15 \\
\hline NCT01038596 & Mesenchymal Stromal Cells and Osteoarthritis & Osteoarthritis & & Dec-09 \\
\hline NCT02495766 & $\begin{array}{l}\text { Autologous Mesenchymal Stromal Cells for Multiple } \\
\text { Sclerosis }\end{array}$ & $\begin{array}{l}\text { Relapsing-Remitting Multiple } \\
\text { Sclerosis| Secondary Progressive } \\
\text { Multiple Sclerosis }\end{array}$ & Drug: XCEL-MC-ALPHA|Drug: Placebo & Nov-15 \\
\hline NCT02565459 & MSC and Kidney Transplant Tolerance (Phase A) & Chronic Renal Failure & Biological: Mesenchymal Stromal Cells & Sep-15 \\
\hline NCT01849237 & $\begin{array}{l}\text { Russian Clinical Trial of Mesenchymal Cells in } \\
\text { Patients With Septic Shock and Severe Neutropenia }\end{array}$ & $\begin{array}{c}\text { Septic Shock| Nonchemotherapy } \\
\text { Drug-induced Neutropenia| } \\
\text { Neutropenia After Chemotherapy } \\
\text { in Oncohematological Patients| } \\
\text { Neutropenia in Patients With Aplastic } \\
\text { Anemia }\end{array}$ & $\begin{array}{l}\text { Genetic: Mesenchymal stromal cells|Drug: } \\
\text { Standard therapy of septic shock }\end{array}$ & May-13 \\
\hline NCT02387151 & $\begin{array}{c}\text { Allogeneic Mesenchymal Stromal Cell Therapy in } \\
\text { Renal Transplant Recipients }\end{array}$ & Rejection|Graft Loss & Procedure: mesenchymal stem cell infusion & Mar-15 \\
\hline NCT01175655 & $\begin{array}{c}\text { A Study to Evaluate the Potential of Mesenchymal } \\
\text { Stromal Cells to Treat Obliterative Bronchiolitis After } \\
\text { Lung Transplantation }\end{array}$ & $\begin{array}{l}\text { Bronchiolitis Obliterans } \mid \text { Lung } \\
\text { Transplantation }\end{array}$ & Other: MSC & Apr-15 \\
\hline NCT00957931 & $\begin{array}{l}\text { Allo-HCT MUD for Non-malignant Red Blood } \\
\text { Cell (RBC) Disorders: Sickle Cell, Thal, and DBA: } \\
\text { Reduced Intensity Conditioning, Co-tx MSCs }\end{array}$ & $\begin{array}{l}\text { Sickle Cell Disease| Thalassemia| } \\
\text { Diamond-Blackfan Anemia }\end{array}$ & $\begin{array}{l}\text { Procedure: Bone marrow transplantation| } \\
\text { Biological: Mesenchymal Stromal Cells }\end{array}$ & Dec-12 \\
\hline NCT01742260 & $\begin{array}{c}\text { Cranial Reconstruction Using Mesenchymal Stromal } \\
\text { Cells and Resorbable Biomaterials }\end{array}$ & Surgically-Created Resection Cavity & $\begin{array}{c}\text { Procedure: Repair of cranial defects by tissue } \\
\text { engineering }\end{array}$ & Jun-15 \\
\hline NCT02260375 & MSC Therapy in Liver Transplantation & Liver Transplant Rejection & Biological: Mesenchymal Stromal Cells & Sep-15 \\
\hline NCT01872624 & $\begin{array}{c}\text { Safety Study of Bone-marrow Derived Mesenchymal } \\
\text { Stromal Cells Associated With Endobronchial Valves } \\
\text { in Emphysema }\end{array}$ & Pulmonary Emphysema & Procedure: Bronchoscopy & Mar-15 \\
\hline NCT01586312 & $\begin{array}{c}\text { Treatment of Knee Osteoarthritis With Allogenic } \\
\text { Mesenchymal Stem Cells }\end{array}$ & $\begin{array}{l}\text { Osteoarthritis, Knee|Arthritis of } \\
\text { Knee|Knee Osteoarthritis }\end{array}$ & $\begin{array}{l}\text { Other: Allogenic mesenchymal stromal cells } \\
\text { injection|Drug: Hyaluronic Acid }\end{array}$ & Sep-15 \\
\hline
\end{tabular}




\begin{tabular}{|c|c|c|c|c|}
\hline NCT01860417 & $\begin{array}{l}\text { Treatment of Degenerative Disc Disease With } \\
\text { Allogenic Mesenchymal Stem Cells (MSV) }\end{array}$ & $\begin{array}{c}\text { Degenerative Disc Disease } \mid \\
\text { Intervertebral Disc Disease|Low Back } \\
\text { Pain }\end{array}$ & $\begin{array}{l}\text { Biological: Allogenic Mesenchymal Stromal } \\
\text { Cells| Drug: Mepivacaine }\end{array}$ & Sep-15 \\
\hline NCT02384018 & $\begin{array}{l}\text { Mesenchymal Stem Cell and Islet } \\
\text { transplantation }\end{array}$ & Chronic Pancreatitis| Diabetes & $\begin{array}{l}\text { Biological: autologous mesenchymal stromal } \\
\text { cell }\end{array}$ & Dec-14 \\
\hline NCT01306513 & $\begin{array}{c}\text { Safety and Feasibility Study of Administration } \\
\text { of Mesenchymal Stem Cells for Treatment of } \\
\text { Emphysema }\end{array}$ & Emphysema & $\begin{array}{l}\text { Biological: autologous bone marrow derived } \\
\text { mesenchymal stromal cells }\end{array}$ & Nov-12 \\
\hline NCT02359929 & BMT Auto MSCs GvHD Ph1 & $\begin{array}{c}\text { Graft Versus Host Disease|Acute Graft } \\
\text { Versus Host Disease|Chronic Graft } \\
\text { Versus Host Disease }\end{array}$ & $\begin{array}{l}\text { Biological: Autologous mesenchymal stromal } \\
\text { cells (MSCs) }\end{array}$ & Aug-15 \\
\hline NCT02585622 & $\begin{array}{c}\text { Novel Stromal Cell Therapy for Diabetic Kidney } \\
\text { Disease }\end{array}$ & Diabetic Kidney Disease & $\begin{array}{l}\text { Biological: Mesenchymal Stromal Cells| Other: } \\
\text { Placebo }\end{array}$ & Oct-15 \\
\hline NCT02033525 & $\begin{array}{c}\text { Mesenchymal Stromal Cells for Degenerative } \\
\text { Meniscus Injury }\end{array}$ & Chronic Meniscal Injury & $\begin{array}{l}\text { Drug: XCEL-M-ALPHA and standard } \\
\text { rehabilitation| Other: Rehabilitation }\end{array}$ & Jul-15 \\
\hline NCT02589119 & $\begin{array}{c}\text { Stem Cell Fistula Plug in Cryptoglandular Perianal } \\
\text { Fistulas (MSC-AFP) }\end{array}$ & $\begin{array}{l}\text { Perianal Fistula| Cryptoglandular } \\
\text { Perianal Fistula }\end{array}$ & Drug: MSC-AFP & Oct-15 \\
\hline NCT02421484 & $\begin{array}{c}\text { Cellular Immunotherapy for Septic Shock: A Phase } \\
\text { I Trial }\end{array}$ & Septic Shock & $\begin{array}{l}\text { Biological: Allogeneic bone marrow derived } \\
\text { mesenchymal stromal cells }\end{array}$ & Apr-15 \\
\hline NCT02055625 & $\begin{array}{l}\text { Mesenchymal Stem Cells as a Treatment for Oral } \\
\text { Complications of Graft-versus-host Disease }\end{array}$ & Graft -Versus-host-disease & Biological: Mesenchymal stromal cells & Mar-15 \\
\hline NCT02408432 & $\begin{array}{l}\text { Intravenous Administration of Allogeneic Bone } \\
\text { Marrow Derived Multipotent Mesenchymal Stromal } \\
\text { Cells (MSCs) in Patients With Recent Onset } \\
\text { Anthracycline-Associated Cardiomyopathy }\end{array}$ & Cardiomyopathy & $\begin{array}{l}\text { Biological: Human Mesenchymal Stem Cells } \\
\text { (hMSCs)|Other: Standard of Care }\end{array}$ & Jun-15 \\
\hline NCT02181478 & Intra-Osseous Co-Transplant of UCB and hMSC & $\begin{array}{c}\text { Acute Lymphoblastic Leukemia| } \\
\text { Acute Myelogenous Leukemia| } \\
\text { Myelodysplastic Syndromes| } \\
\text { Myelofibrosis| Relapsed Non-Hodgkin } \\
\text { Lymphoma| Refractory Non-Hodgkin } \\
\text { Lymphoma| Hodgkin Lymphoma| } \\
\text { Refractory Hodgkin Lymphoma| } \\
\text { Relapsed Chronic Lymphocytic } \\
\text { Leukemia| Refractory Chronic } \\
\text { Lymphocytic Leukemia| Lymphoid } \\
\text { Malignancies| Chronic Myelogenous } \\
\text { Leukemia }\end{array}$ & $\begin{array}{c}\text { Drug: cyclophosphamide| Drug: } \\
\text { fludarabine phosphate| Radiation: total- } \\
\text { body irradiation|Drug: cyclosporine|Drug: } \\
\text { mycophenolatemofetil|Procedure: umbilical cord } \\
\text { blood transplantation| Procedure: mesenchymal } \\
\text { stem cell transplantation }\end{array}$ & Jul-15 \\
\hline NCT02351011 & $\begin{array}{l}\text { Human Autologous MSCs for the Treatment of Mid } \\
\text { to Late Stage Knee OA }\end{array}$ & Osteoarthritis of Knee & $\begin{array}{l}\text { Biological: } 1 \times 10^{\wedge} 6 \mathrm{MSCs} \mid \text { Biological: } 10 \mathrm{x} \\
10^{\wedge} 6 \mathrm{MSCs} \mid \text { Biological: } 50 \times 10^{\wedge} 6 \mathrm{MSCs}\end{array}$ & Feb-15 \\
\hline NCT02270307 & $\begin{array}{l}\text { MSC and Cyclophosphamide for Acute Graft-Versus- } \\
\text { Host Disease (aGVHD) Prophylaxis }\end{array}$ & Leukemia| Multiple Myeloma & $\begin{array}{l}\text { Drug: Cyclophosphamide| Biological: } \\
\text { Mesenchymal stromal cells }\end{array}$ & Oct-14 \\
\hline NCT01922908 & Mesenchymal Stromal Cells for Ischemic Stroke & Ischemic Stroke & $\begin{array}{c}\text { Biological: MSC Infusion|Biological: Placebo } \\
\text { Comparator }\end{array}$ & May-15 \\
\hline NCT02145923 & $\begin{array}{l}\text { Effectiveness and Safety of MMSCs for Enhancing } \\
\text { Hematopoietic Recovery and Prophylaxis of } \\
\text { Neutropenic Enterocolitis }\end{array}$ & $\begin{array}{c}\text { NeutropenicEnterocolitis } \mid \\
\text { Myeloablative Chemotherapy Induced } \\
\text { Bone Marrow Aplasia }\end{array}$ & $\begin{array}{l}\text { Procedure: Peripheral blood stem cell } \\
\text { mobilisation and collection|Drug: High-dose } \\
\text { chemotherapy| Drug: Bone marrow derived } \\
\text { allogeneic MMSCs infusion|Procedure: } \\
\text { Autologous peripheral blood stem cells infusion }\end{array}$ & Jun-15 \\
\hline NCT01275612 & $\begin{array}{l}\text { Mesenchymal Stem Cells In Cisplatin-Induced Acute } \\
\text { Renal Failure In Patients With Solid Organ Cancers }\end{array}$ & Solid Tumors| Acute Kidney Injury & Biological: Mesenchymal stromal cell infusion & Oct-15 \\
\hline NCT01909154 & $\begin{array}{l}\text { Safety Study of Local Administration of Autologous } \\
\text { Bone Marrow Stromal Cells in Chronic Paraplegia }\end{array}$ & Spinal Cord Injury & Biological: Mesenchymal stromal cell therapy & Nov-13 \\
\hline NCT00395200 & $\begin{array}{c}\text { Mesenchymal Stem Cells in Multiple Sclerosis } \\
\text { (MSCIMS) }\end{array}$ & Multiple Sclerosis & Procedure: MSC Treatment & Oct-11 \\
\hline NCT00260338 & $\begin{array}{l}\text { Stem Cell Therapy for Vasculogenesis in Patients } \\
\text { With Severe Myocardial Ischemia }\end{array}$ & $\begin{array}{c}\text { Myocardial Ischemia| Coronary Heart } \\
\text { Disease }\end{array}$ & Biological: stem cell & May-13 \\
\hline NCT01659762 & $\begin{array}{c}\text { A Phase I Study Evaluating Autologous Bone } \\
\text { Marrow Derived Mesenchymal Stromal for Crohn's } \\
\text { Disease. }\end{array}$ & Crohn's Disease & $\begin{array}{l}\text { Biological: autologous mesenchymal stromal } \\
\text { cell }\end{array}$ & Jul-15 \\
\hline NCT02382874 & $\begin{array}{l}\text { Allogenic AD-MSC Transplantation in Idiopathic } \\
\text { Nephrotic Syndrome (Focal Segmental } \\
\text { Glomerulosclerosis) }\end{array}$ & Focal Segmental Glomerulosclerosis & Biological: Intravenous injection & Mar-15 \\
\hline NCT02448849 & $\begin{array}{c}\text { Autologous BM-MSC Transplantation in } \\
\text { Combination With Platelet Lysate (PL) for Nonunion } \\
\text { Treatment }\end{array}$ & Bone Fracture & $\begin{array}{l}\text { Biological: Percutaneous injection| Other: } \\
\text { Percutaneous injection }\end{array}$ & Sep-15 \\
\hline NCT01915927 & Stem Cell Fistula Plug in Perianal Crohn's Disease & Perianal Crohn's Disease & Drug: MSC-AFP & Jun-15 \\
\hline NCT01686139 & $\begin{array}{c}\text { Safety Study of Stem Cells Treatment in Diabetic } \\
\text { Foot Ulcers }\end{array}$ & $\begin{array}{l}\text { Type I Diabetes Mellitus With Ulcer| } \\
\text { Type II Diabetes Mellitus With Ulcer }\end{array}$ & Biological: ABMD-MSC & Jan-14 \\
\hline NCT02017912 & $\begin{array}{l}\text { Phase 2, Randomized, Double Blind, Placebo } \\
\text { Controlled Multicenter Study of Autologous MSC- } \\
\text { NTF Cells in Patients With ALS }\end{array}$ & Amyotrophic Lateral Sclerosis (ALS) & Biological: Autologous MSC-NTF cells & Jul-15 \\
\hline
\end{tabular}




\begin{tabular}{|c|c|c|c|c|}
\hline NCT01463475 & $\begin{array}{l}\text { University of Wisconsin hMSC Cell Bank: Bone } \\
\text { Marrow Donor Protocol }\end{array}$ & $\begin{array}{c}\text { Graft Versus Host Disease } \\
\text { (GVHD)|Acute Myocardial Infarction } \\
\text { (AMI) }\end{array}$ & Procedure: Bone marrow aspirate & Dec-14 \\
\hline NCT02195323 & $\begin{array}{c}\text { Autologous Bone Marrow Derived Mesenchymal } \\
\text { Stromal Cells (BM-MSCs) in Patients With Chronic } \\
\text { Kidney Disease (CKD) }\end{array}$ & Chronic Kidney Disease & Biological: Intravenous injection & Oct-13 \\
\hline NCT02409940 & $\begin{array}{l}\text { To Elucidate the Effect of Mesenchymal Stem Cells } \\
\text { on the T Cell Repertoire of the Kidney Transplant } \\
\text { Patients }\end{array}$ & Renal Transplant Rejection & Biological: Mesenchymal Stem Cells & Apr-15 \\
\hline NCT00908856 & Autologous Cell Therapy After Stroke & Stroke & $\begin{array}{l}\text { Biological: autologous bone marrow } \\
\text { mononuclear cell transfusion| Biological: } \\
\text { marrow stromal cells| Drug: placebo }\end{array}$ & Dec-14 \\
\hline NCT02247973 & $\begin{array}{l}\text { Mesenchymal Stem Cells Co-transplantation in } \\
\text { Alternative Donor Transplantation of Severe Aplastic } \\
\text { Anemia. }\end{array}$ & Severe Aplastic Anemia & $\begin{array}{c}\text { Biological: mesenchymal stem cells| Biological: } \\
\text { mesenchymal stem cells }\end{array}$ & Sep-14 \\
\hline NCT01446614 & $\begin{array}{l}\text { Mesenchymal Stem Cells Transplantation to Patients } \\
\text { With Parkinson's Disease }\end{array}$ & Parkinson's Disease & $\begin{array}{l}\text { Biological: bone marrow derived mesenchymal } \\
\text { stem cells }\end{array}$ & Oct-11 \\
\hline NCT01446640 & $\begin{array}{l}\text { Mesenchymal Stem Cells Transplantation to Patients } \\
\text { With Spinal Cord Injury }\end{array}$ & Spinal Cord Injury & $\begin{array}{l}\text { Biological: bone marrow derived mesenchymal } \\
\text { stem cells }\end{array}$ & Oct-11 \\
\hline NCT01305694 & $\begin{array}{l}\text { Mesenchymal Stem Cells Transplantation to Patients } \\
\text { With Relapsed/Refractory Aplastic Anemia. }\end{array}$ & Aplastic Anemia & $\begin{array}{c}\text { Biological: bone marrow derived mesenchymal } \\
\text { stem cells }\end{array}$ & Feb-11 \\
\hline NCT01051882 & $\begin{array}{l}\text { Autologous Cultured Mesenchymal Bone Marrow } \\
\text { Stromal Cells Secreting Neurotrophic Factors (MSC- } \\
\text { NTF), in ALS Patients. }\end{array}$ & Amyotrophic Lateral Sclerosis & $\begin{array}{l}\text { Biological: MSC-NTF cells transplantation } \\
\text { (i.m.)| Biological: MSC-NTF cells } \\
\text { transplantation (i.t.) }\end{array}$ & Aug-12 \\
\hline NCT01624701 & $\begin{array}{l}\text { Clinical Ex Vivo Expansion of Human Umbilical } \\
\text { Cord Blood Stem and Progenitor Cells }\end{array}$ & $\begin{array}{l}\text { Acute Leukemia| Chronic Leukemia| } \\
\text { Myelodysplastic Syndrome| } \\
\text { Lymphoma| Myeloma }\end{array}$ & Other: Ex-vivo expanded cord blood cells & Jun-12 \\
\hline NCT02336230 & $\begin{array}{l}\text { A Prospective Study of Remestemcel-L, Ex-vivo } \\
\text { Cultured Adult Human Mesenchymal Stromal Cells, } \\
\text { for the Treatment of Pediatric Patients Who Have } \\
\text { Failed to Respond to Steroid Treatment for Acute } \\
\text { GVHD }\end{array}$ & Grades B-D aGVHD & Drug: Remestemcel-L & Jan-15 \\
\hline NCT02525432 & $\begin{array}{l}\text { Autologous Stem Cell Study for Adult TBI (Phase } \\
\qquad 2 \mathrm{~b} \text { ) }\end{array}$ & $\begin{array}{l}\text { Brain Injuries, Traumatic| Brain } \\
\text { Injuries, Acute| TBI (Traumatic Brain } \\
\text { Injury) }\end{array}$ & $\begin{array}{l}\text { Biological: Placebo Infusion| Biological: } \\
\text { Autologous BMMNC Infusion| Device: } \\
\text { Ultrasound }\end{array}$ & Oct-15 \\
\hline NCT02209311 & $\begin{array}{l}\text { Effectiveness and Safety of Method of Maxilla } \\
\text { Alveolar Process Reconstruction Using Synthetic } \\
\text { Tricalcium Phosphate and Autologous MMSCs }\end{array}$ & $\begin{array}{l}\text { Partially Edentulous Maxilla| Alveolar } \\
\text { Bone Atrophy| Alveolar Bone Loss }\end{array}$ & $\begin{array}{l}\text { Procedure: Oral mucosa biopsy| Procedure: } \\
\text { Sinus lift with implantation of tissue engineered } \\
\text { construction| Device: Dental implant }\end{array}$ & Sep-15 \\
\hline NCT02379442 & $\begin{array}{l}\text { Early Treatment of Acute Graft Versus Host Disease } \\
\text { With Bone Marrow-Derived Mesenchymal Stem } \\
\text { Cells and Corticosteroids }\end{array}$ & Graft-Versus-Host Disease & Biological: MSC & Feb-15 \\
\hline NCT01144962 & $\begin{array}{l}\text { Dose-escalating Therapeutic Study of Allogeneic } \\
\text { Bone Marrow Derived Mesenchymal Stem Cells for } \\
\text { the Treatment of Fistulas in Patients With Refractory } \\
\text { Perianal Crohn's Disease }\end{array}$ & Crohn's Disease| Fistula & $\begin{array}{l}\text { Procedure: Localization, curettage of the } \\
\text { fistulous tract and closure of the internal opening } \\
\text { without MSC injection.| Procedure: Localization, } \\
\text { curettage of the fistulous tract and closure of the } \\
\text { internal opening with local MSC injection. }\end{array}$ & Dec-14 \\
\hline NCT02448121 & $\begin{array}{l}\text { Autologous Bone Marrow Stem Cell Transplantation } \\
\text { for Hip Osteonecrosis in Sickle Cell Disease }\end{array}$ & $\begin{array}{l}\text { Avascular Necrosis of Femur Head } \\
\text { Sickle Cell Disease }\end{array}$ & $\begin{array}{l}\text { Procedure: Stem Cell Graft Group| Biological: } \\
\text { Autologous bone marrow stem cell }\end{array}$ & Aug-15 \\
\hline NCT01892514 & $\begin{array}{c}\text { Randomized Clinical Trial for the Treatment of } \\
\text { Osteonecrosis of the Femoral Head }\end{array}$ & Osteonecrosis & Procedure: core decompression & Apr-14 \\
\hline NCT02249676 & $\begin{array}{c}\text { Autologous Mesenchymal Stem Cells for the } \\
\text { Treatment of NeuromyelitisOptica Spectrum } \\
\text { Disorders }\end{array}$ & $\begin{array}{c}\text { Devic's Syndrome| } \\
\text { Devic'sNeuromyelitisOptica| Devic } \\
\text { Syndrome| Devic's Disease| Devic } \\
\text { Disease }\end{array}$ & Biological: Autologous mesenchymal stem cells & Sep-14 \\
\hline NCT02482194 & $\begin{array}{l}\text { Autologous Mesenchymal Stem Cells Transplantation } \\
\text { for Spinal Cord Injury- A Phase I Clinical Study }\end{array}$ & Spinal Cord Injury & Biological: mesenchymal stem cells & Jun-15 \\
\hline NCT00731744 & $\begin{array}{c}\text { Generation of Dendritic Cell Precursors From Cord } \\
\text { Blood Stem Cells }\end{array}$ & Normal Full-Term Deliveries & Procedure: Normal full-term deliveries & Aug-08 \\
\hline NCT02037204 & $\begin{array}{l}\text { IMPACT: Safety and Feasibility of a Single-stage } \\
\text { Procedure for Focal Cartilage Lesions of the Knee. }\end{array}$ & $\begin{array}{l}\text { Foreign-Body Reaction| Inflammation| } \\
\text { Effusion (L) Knee| Knee Pain Swelling }\end{array}$ & Other: Cartilage repair surgery & Jul-14 \\
\hline NCT01993368 & $\begin{array}{c}\text { Analysis of Osteoimmune Interactions Linking } \\
\text { Inflammation and Bone Destruction in Aggressive } \\
\text { Periodontitis }\end{array}$ & $\begin{array}{l}\text { Aggressive Periodontitis| Chronic } \\
\text { Periodontitis }\end{array}$ & Other: flow cytometry & Sep-15 \\
\hline NCT01777646 & $\begin{array}{c}\text { Autologous Cultured Mesenchymal Bone Marrow } \\
\text { Stromal Cells Secreting Neurotrophic Factors (MSC- } \\
\text { NTF), in Patients With Amyotrophic Lateral Sclerosis } \\
\text { (ALS) }\end{array}$ & Amyotrophic Lateral Sclerosis & $\begin{array}{c}\text { Biological: MSC_NTF cells transplantation by } \\
\text { multiple intramuscular injections at } 24 \text { separate } \\
\text { sites, in addition to a single intrathechal injection } \\
\text { into the CSF }\end{array}$ & Jan-14 \\
\hline NCT01468064 & $\begin{array}{l}\text { Autologous Bone Marrow Stromal Cell and } \\
\text { Endothelial Progenitor Cell Transplantation in } \\
\text { Ischemic Stroke }\end{array}$ & $\begin{array}{l}\text { Stroke| Infarction, Middle Cerebral } \\
\text { Artery }\end{array}$ & $\begin{array}{l}\text { Genetic: Autologous BMSCs transplantation| } \\
\text { Genetic: Autologous EPCs transplantation| } \\
\text { Genetic: IV infusion of placebo }\end{array}$ & Nov-15 \\
\hline
\end{tabular}




\begin{tabular}{|c|c|c|c|c|}
\hline NCT01071577 & $\begin{array}{l}\text { Collection of Bone Marrow From Healthy Volunteers } \\
\text { and Patients for the Production of Clinical Bone } \\
\text { Marrow Stromal Cell (BMSC) Products }\end{array}$ & $\begin{array}{l}\text { Bone Marrow| Bone Marrow Stromal } \\
\text { Cells } \mid \text { Mesenchymal Stem Cells } \mid \text { Blood } \\
\text { Donors }\end{array}$ & & Aug-15 \\
\hline NCT00186914 & $\begin{array}{c}\text { Stromal Therapy of Osteodysplasia After Allogeneic } \\
\text { Bone Marrow Transplantation }\end{array}$ & Osteodysplasia & Biological: Marrow stromal cell infusion & Feb-08 \\
\hline NCT00781872 & Mesenchymal Stem Cells for the Treatment of MS & Multiple Sclerosis & Biological: injection of autologous stem cells & Oct- 08 \\
\hline NCT02467387 & $\begin{array}{c}\text { A Study to Assess the Effect of Intravenous Dose } \\
\text { of (aMBMC) to Subjects With Non-ischemic Heart } \\
\text { Failure }\end{array}$ & Non-Ischemic Heart Failure & $\begin{array}{l}\text { Drug: Allogeneic Mesenchymal Bone Marrow } \\
\text { Cells (aMBMC)| Drug: Lactated Ringer's } \\
\text { Solution }\end{array}$ & Jun-15 \\
\hline NCT02442817 & $\begin{array}{l}\text { Linagliptin and Mesenchymal Stem Cells: A Pilot } \\
\text { Study }\end{array}$ & Schizophrenia & Drug: Linagliptin & Apr-15 \\
\hline NCT02064062 & Autologous Stem Cells in Achilles Tendinopathy & $\begin{array}{c}\text { Achilles Tendinitis, Right Leg } \mid \text { Achilles } \\
\text { Tendinitis } \mid \text { Achilles Degeneration|Achilles } \\
\text { Tendon Thickening| Tendinopathy| Achilles } \\
\text { Tendinitis, Left Leg }\end{array}$ & $\begin{array}{l}\text { Biological: Autologous Mesenchymal Stem } \\
\text { Cells }\end{array}$ & Feb-14 \\
\hline NCT01840540 & MSC for Occlusive Disease of the Kidney & $\begin{array}{c}\text { Atherosclerotic Renal Artery Stenosis| } \\
\text { Ischemic Nephropathy| Renovascular } \\
\text { Hypertension }\end{array}$ & $\begin{array}{l}\text { Drug: Arterial infusion of autologous } \\
\text { mesenchymal stem cells }\end{array}$ & Oct-15 \\
\hline NCT01795950 & $\begin{array}{c}\text { Safety Study of PLX-PAD Cells to Treat Pulmonary } \\
\text { Arterial Hypertension (PAH) }\end{array}$ & Pulmonary Arterial Hypertension & Drug: PLX-PAD & Sep-15 \\
\hline NCT01377870 & $\begin{array}{l}\text { Evaluation of Autologous Mesenchymal Stem Cell } \\
\text { Transplantation (Effects and Side Effects) in Multiple } \\
\text { Sclerosis }\end{array}$ & Multiple Sclerosis & $\begin{array}{c}\text { Biological: intravenous injection of } \\
\text { mesenchymal stem cells| Biological: injection of } \\
\text { cell free media }\end{array}$ & Aug-10 \\
\hline NCT01557543 & $\begin{array}{l}\text { Stem Cell Injection to Treat Heart Damage During } \\
\text { Open Heart Surgery }\end{array}$ & $\begin{array}{c}\text { Heart Disease| Ischemic Heart Disease } \mid \\
\text { Coronary Artery Disease| Coronary } \\
\text { Artery Disease (CAD) }\end{array}$ & Other: Cell Therapy & Nov-15 \\
\hline NCT00919958 & $\begin{array}{c}\text { Safety of Intramuscular Injection of Allogeneic } \\
\text { PLX-PAD Cells for the Treatment of Critical Limb } \\
\text { Ischemia }\end{array}$ & $\begin{array}{l}\text { Peripheral Artery Disease| Peripheral } \\
\text { Vascular Disease| Critical Limb } \\
\text { Ischemia }\end{array}$ & Biological: PLX-PAD IM injection & Jun-12 \\
\hline NCT00951210 & $\begin{array}{c}\text { Safety of Intramuscular Injections (IM) of Allogeneic } \\
\text { PLX-PAD Cells for the Treatment of Critical Limb } \\
\text { Ischemia (CLI) }\end{array}$ & $\begin{array}{l}\text { Peripheral Artery Disease| Peripheral } \\
\text { Vascular Disease| Critical Limb } \\
\text { Ischemia }\end{array}$ & Biological: PLX-PAD & Nov-11 \\
\hline NCT02323477 & $\begin{array}{l}\text { Human Umbilical Cord Stroma MSC in Myocardial } \\
\text { Infarction }\end{array}$ & $\begin{array}{l}\text { Chronic Ischemic Cardiomyopathy| } \\
\text { Coronary Artery Bypass Surgery }\end{array}$ & Biological: stem cell transplantation & May-15 \\
\hline NCT01849159 & $\begin{array}{c}\text { Clinical Study of the Efficacy and Safety of the } \\
\text { Application of Allogeneic Mesenchymal (Stromal) } \\
\text { Cells of Bone Marrow, Cultured Under the Hypoxia } \\
\text { in the Treatment of Patients With Severe Pulmonary } \\
\text { Emphysema }\end{array}$ & Pulmonary Emphysema & $\begin{array}{c}\text { Biological: Mesenchymal stem cells| Other: } \\
\text { Reference therapy: } 400 \mathrm{~mL} \text { of } 0.9 \% \mathrm{NaCl} \\
\text { solution }\end{array}$ & Oct-15 \\
\hline NCT00821470 & $\begin{array}{c}\text { Treatment of Osteonecrosis of the Femoral Head by } \\
\text { Bone Marrow Transplantation }\end{array}$ & Necrosis & $\begin{array}{l}\text { Procedure: core decompression| Procedure: Bone } \\
\text { marrow implantation into the necrotic lesion }\end{array}$ & Jan-09 \\
\hline NCT01172548 & $\begin{array}{c}\text { Safety and Efficacy Evaluation of Two Year Imatinib } \\
\text { Treatment in Adjuvant Gastrointestinal Stromal } \\
\text { Tumor (GIST) }\end{array}$ & Gastrointestinal Stromal Tumors & Drug: Imatinibmesylate & Mar-15 \\
\hline
\end{tabular}

\section{MSCs applications in radiation oncology regenerative medicine (RORM)}

Adding up all their beneficial characteristics, MSCs have been investigated in RORM preclinical and clinical studies (Table 2). Nevertheless, the few clinical data representing the therapeutic benefits of the application of MSCs in radiation-induced normal tissue injury are promising. Among these, in radiation-induced bone injury, MSCs therapy caused early hematopoietic recovery with improved osteonecrosis. In radiation-induced intestinal injury, MSCs therapy produced significant repopulation of intestinal epithelium with reduced pain, diarrhea, and hemorrhage. In radiation-induced skin injury, MSCs therapy showed significant improvement and repopulation of skin tissue [29]. The following are the clinical studies that have been investigating the potential application of MSCs in RORM.

\section{Skin repair application after radiation exposure}

MSCs have been used in the repair of radiation-induced skin injuries where they were administered systemically and led to decreased radiation-induced skin fibrosis through enhancing the secretion of IL-10 and increasing the infiltration of anti-inflammatory regulatory CD163(+) macrophages, in addition to decreasing the secretionof
IL-1 beta and the number of infiltrated pro-inflammatory CD80(+) macrophages [36]. It was suggested that the autologous grafting of MSCs is more efficient than the allogenic grafting in cutaneous radiation syndrome [20]. MSCs secrete growth factors and anti-inflammatory mediators that can be combined with other external growth factors, e.g. basic fibroblast growth factor (b-FGF) in order to improve the healing in radiation-induced skin damage [37]. The improved migration of fibroblasts and collagen production will protect the fibroblasts from the oxidative stress of UVB radiation [37].

\section{Intestinal repair application after radiation exposure}

MSCs have been applied for the repair of radiation-induced intestinal injury [26,38]. When MSCs were given before irradiation, treated mice showed higher body weight, thicker intestinal submucosal and muscle layer, significant higher survival rates and stromal derived factor-1 (SDF-1) expression, and lower numbers of radiation-induced ulcers [25,38]. Another study reported that MSCs therapy showed better maintenance of epithelial homeostasis, neovascularization, high anti-inflammatory IL-10, increased expression of VEGF, b-FGF and EGF in irradiated intestine, and increased the homing of CD31positive hematopoietic stem cells or hematopoietic progenitor cells to the irradiated intestine [39]. MSCs therapy showed decreased 


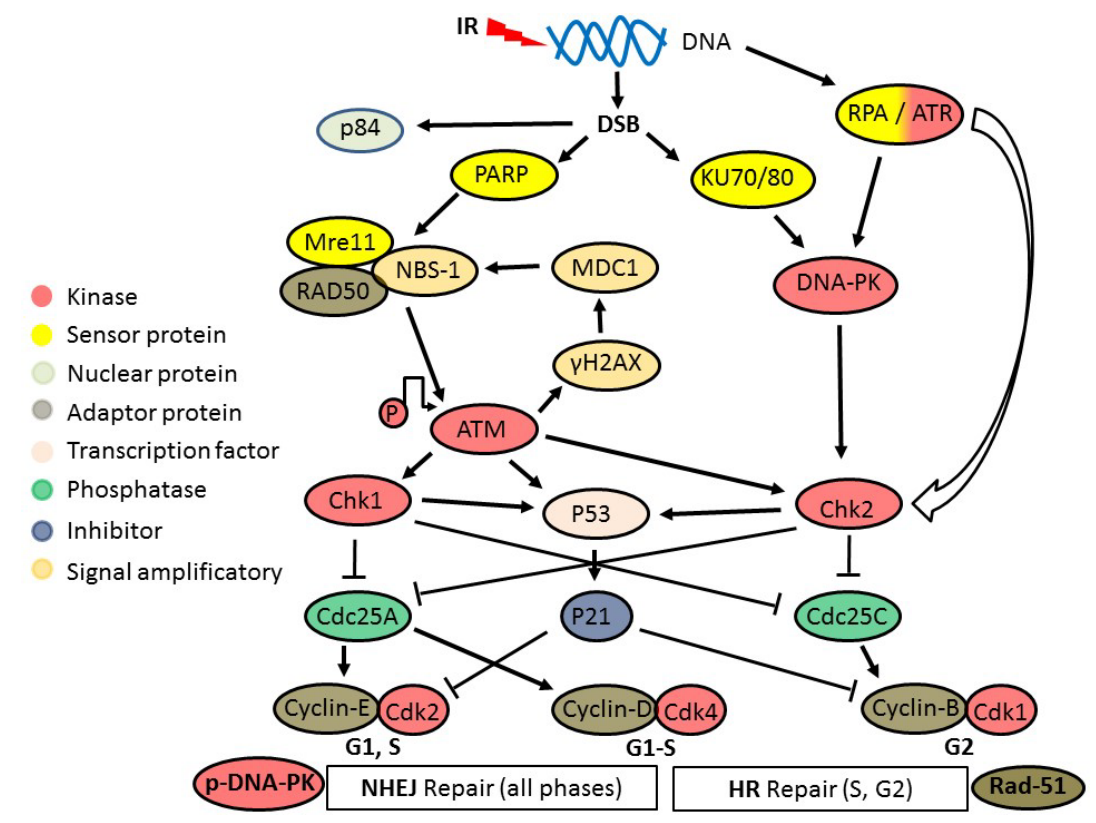

Figure 2.MSCs radiobiological response

Double stranded DNA (dsDNA) breaks (DSB) resulting from the direct and indirect radiation injury stimulate the phosphorylation of Ataxia Telangectasia Mutated protein (ATM) which is the proximal step for cell cycle check points activation (G2/M arrest). The nuclear apoptotic factor P84 is up regulated, which participates in the apoptotic response of the cells. DSB stimulate the phosphorylation of histone-2AX through the Mre11, RAD50, NBS1 complex and p-ATM with a feedback loop amplification. Phosphorylated histone-2AX ( $\gamma$-H2AX) stimulated both the homologous recombination repair (HR, active in S and G2 phases only) and the non-homologous end-joining repair (NHEJ, active in all cell cycle phases) of the DSB. Rad-51 is considered one of the mandatory proteins for HR to occur. DNA-PK is the major protein in the NHEJ repair pathway. Both proteins were up regulated in irradiated MSCs. P-ATM and p-DNA-PK activate the cell cycle check point kinases (Chk1 and Chk2) resulting in cyclin/Cdk-mediated G2/M cell cycle arrest by inhibiting the Cell division cycle phosphatase (Cdc25). P-ATM also stabilizes the tumor suppressor regulatory protein and transcription factor $\mathbf{P 5 3}$ which up-regulates the expression and enhances the stabilization of the inhibitory regulatory protein $\mathbf{p 2 1}$, which potently inhibits Cdks needed for the G1/S transition leading to inhibition of the entry into S phase.

activation and proliferation of T-lymphocytes together with increased local corticosterone secretion at the intestinal mucosa that highlighted an immunosuppressive effect of MSCs mediated by glucocorticoid receptors [40]. It was found that MSCs reparative and paracrine effects in radiation-induced intestinal injury were enhanced by pretreating them with TNF-alpha, IL-1 beta, and nitric oxide [41].

\section{Lung tissue repair application after radiation exposure}

MSCs therapy was shown to reduce radiation-induced lung tissue injury. Administration of MSCs resulted in decreased radiationinduced inflammatory response in terms of reduced pro-inflammatory mediators (IL-1 beta, IL-6, TNF-alpha), increased anti-inflammatory mediators (IL-10), reduced expression of TGF- $\beta$, alpha-smooth muscle actin (Alpha-SMA) and type 1 collagen level, and control of the proand anti-apoptotic mediators (Bcl-2, Bax, and caspase-3) protecting the lung tissue from apoptosis [42]. Moreover, MSCs therapy reduced bronchial epithelium senescence and lowered the risk of metastatic spread in lung tissue [43]. In addition, MSCs therapy decreased the mortality rate in mice with radiation-induced lung injury [44]. These cells showed a proven beneficial therapeutic effect in radiation pneumonitis as well [45].

\section{Hematopoietic system homeostasis radiation injury}

MSCs therapy has been shown to reduce the radiation-induced bone marrow apoptosis, and enhancemegakaryopoiesis and platelet recovery [46]. Moreover, MSCs therapy resulted in improved recovery of the hematopoietic system through decreased apoptosis and radiation-induced oxidative stress $[47,48]$.

\section{Radiation-induced cardiac injuries}

A case report of a patient suffering from late radiation cardiomyopathy and radiation exudative pericarditis after radiotherapy of Hodgkin lymphoma showed that systemically transplanted MSCs partially differentiated to cardiomyocytes [49].

\section{Radiation-induced salivary gland injury}

In irradiated mice, systemically transplanted MSCs resulted in improvement of the saliva flow rate, lower salivary gland damage and atrophic acini, and higher mucin and amylase production [50].

\section{Radiation-induced oral mucositis}

Bone marrow-derived mesenchymal stromal cells (bmMSCs) therapy have been applied in fractionated radiation-induced oral mucositis where the administration of a systemic single dose of 6 million MSCs resulted in a significant decrease in ED50 (the RT dose that produces ulcer in $50 \%$ of irradiated mice) [51]. The first MSCs therapy for RIOM was done in 2014 by Schmidt et al. and concluded that transplantation of bone marrow (BM) or bmMSCs could modulate RIOM in fractionated RT, depending on the time of plantation [52]. Nevertheless, in another study they also concluded that bmMSCs plantation had no therapeutic benefits on RIOM in single dose RT when compared to the therapeutic gain by the mobilization of endogenous BM stem cells [53]. Further studies are needed in this field since the initial studies showed significant clinically relevant therapeutic effects.

\section{Liver tissue protection}

MSCs therapy reduced the radiation-induced liver injury by anti-oxidative, vascular protection, hepatocyte differentiation, and 
Table 2. Mesenchymal stromal/stem cells (MSCs) preclinical and clinical studies in RORM [53,55].

\begin{tabular}{|c|c|c|c|c|c|c|}
\hline $\begin{array}{l}\text { Organ/ } \\
\text { system }\end{array}$ & $\begin{array}{l}\text { RT } \\
\text { dose } \\
(\text { Gy) }\end{array}$ & Normal Tissue Endpoint & Paradigm & $\begin{array}{c}\text { Stem cell type } \\
\text { therapy } \\
\text { (preclinical studies) }\end{array}$ & $\begin{array}{l}\text { Stem cell type } \\
\text { therapy (clinical trial) }\end{array}$ & $\begin{array}{l}\text { Follow } \\
\text { up time }\end{array}$ \\
\hline Bone marrow & 12 & Bone marrow aplasia & $\begin{array}{l}\text { Hematopoietic stem cell/progenitor depletion and } \\
\text { stem cell "niche" destruction }\end{array}$ & $\mathrm{BM}, \mathrm{hSC}, \mathrm{bmMSC}$ & $\mathrm{BM}(81)$ & 30 years \\
\hline Brain & $>57$ & $\begin{array}{l}\text { Brain radio-necrosis, } \\
\text { cognitive dysfunction }\end{array}$ & $\begin{array}{c}\text { Inflammation, vascular breakdown, disruption } \\
\text { of BBB, CNS progenitor depletion, stem cell } \\
\text { "niche" destruction, hypoxia, demyelination, } \\
\text { necrosis }\end{array}$ & hESC, hNSC & No & - \\
\hline $\begin{array}{l}\text { Salivary } \\
\text { glands }\end{array}$ & $>35$ & Xerostomia, salivary flow & Stem cell/progenitor depletion & $\begin{array}{l}\text { BM, bmMSC, salivary } \\
\text { gland stem cell }\end{array}$ & No & - \\
\hline Bone & $>60$ & $\begin{array}{l}\text { Bone growth alteration, } \\
\text { bone weakening, and osteo- } \\
\text { radionecrosis }\end{array}$ & $\begin{array}{l}\text { Hypocellularity, hypovascularization, hypoxia, } \\
\text { and fibro-necrosis }\end{array}$ & $\mathrm{BM}, \mathrm{bmMSC}$ & $\begin{array}{l}\text { BM associated to biomaterial } \\
\text { (Phase I) }\end{array}$ & Few months \\
\hline Skin & $>50$ & Skin radionecrosis, pain & $\begin{array}{c}\text { Chronic inflammation, damage to the } \\
\text { microvasculature, epidermis stem cell/ progenitor } \\
\text { depletion, ischemia, fibroblast death, and fibro- } \\
\text { necrosis }\end{array}$ & bmMSC, aMSCs, EPC & $\begin{array}{l}\text { bmMSC (local injection, } 2 \times 10^{6} \\
\mathrm{~kg} \text {, repetitive injections, curative } \\
\text { startegy) (compatio-nnal treatment) } \\
\text { and lipoaspira-te (PhaseI) }\end{array}$ & $\begin{array}{l}8 \text { years and } \\
13 \text { months }\end{array}$ \\
\hline Liver & $>35$ & $\begin{array}{l}\text { Radiation-induced liver } \\
\text { disease, sinusoidal } \\
\text { obstructive syndrome }\end{array}$ & $\begin{array}{l}\text { Vascular (sinusoidal) breakdown, hepatocyte } \\
\text { cell death, and inhibition of hepatocellular } \\
\text { regeneration }\end{array}$ & Hepatocyte & $\begin{array}{l}\text { Hepatocy-te (intraspel-nic transplan- } \\
\text { tation, } 6 \times 10^{6} \text { cells) (Phase I) }\end{array}$ & - \\
\hline Heart & $>30-40$ & $\begin{array}{l}\text { Atheroscler-osis, cardiac } \\
\text { attack }\end{array}$ & $\begin{array}{l}\text { Inflammation, damage to the microvasculature, } \\
\text { ischemia, myocardial cell death, and fibro-necrosis }\end{array}$ & - & No & - \\
\hline Colon-rectum & $>35$ & $\begin{array}{l}\text { Pelvic radiation disease, } \\
\text { colo-rectal ulceration, } \\
\text { rectitis, cystitis, and fistulae }\end{array}$ & $\begin{array}{c}\text { Chronic inflammation, damage to the } \\
\text { microvasculature, epithelial stem cell/progenitor } \\
\text { depletion, ischemia, myofibroblast death, and } \\
\text { fibro-necrosis }\end{array}$ & bmMSC & $\begin{array}{l}\text { bmMSC (i.v. injection, } 2 \times 10^{6} / \mathrm{kg} \\
\text { repetitive injections) (compass-ional } \\
\text { treatment) }\end{array}$ & 4 years \\
\hline
\end{tabular}

aMSCs = adipose-derived mesenchymal stromal cell, $\mathbf{b m M S C}=$ bone marrow MSCs; $\mathbf{B B B}=$ blood brain barrier; $\mathbf{B M}=$ bone marrow; $\mathbf{C N S}=$ central nervous system; $\mathbf{E P C}=$ endothelial progenitor cells; GFAP $=$ glial fibrillary acidic protein $\mathbf{h E S C}=$ human embryonic stem cell; $\mathbf{h S C}=$ human stem cells; $\mathbf{h N S C}=$ human neural stem cell, $\mathbf{R T}=$ radiation .

trophic mechanisms. There was decreased expression of Nrf2 and superoxide dismutase (SOD) in MSCs-treated irradiated liver which showed decreased apoptotic cells as well.These findings suggested that, these effects were mediated by an anti-oxidative mechanism. The increased expression of VEGF and Angiopoietin-1 (Ang-1) in the perivascular region, associated with an increased expression of VEGFr1, r2 suggested the vascular protection mechanism in the livers of MSCs-treated animals. After engrafting, MSCs showed expression of cytokeratin CK18 and CK19 and alpha-fetoprotein (AFP) genes which suggested hepatocyte differentiation. The increased secretion of nerve growth factor (NGF), hepatocyte growth factor (HGF), and anti-inflammatory molecules IL-10, IL1-RA suggested MSCs' trophic effects $[40,54]$. MSCs conditioned media improved the viability of liver sinusoidal endothelial cells (SECs) in vitro. Infusion of MSCs conditioned media significantly reduced the radiation-induced SECs apoptosis and improved the histopathological picture of irradiated livers. In addition, there was increased secretion of anti-inflammatory cytokines and decreased secretion of pro-inflammatory cytokines $[40,55]$.

\section{Studies with gene-modified MSCs for RORM}

Genetically modified MSCs have been applied in RORM studies. HGF-expressing MSCs have improved the radiation-induced intestinal injury where they increased the expression of anti-inflammatory mediators and improved the histopathological picture of irradiated intestine [12]. Hepatocyte growth factor gene-modified adiposederived mesenchymal stem cells improved the radiation induced liver damage in a rat model [13]. A similar picture was noted with TGFbeta-expressing MSCs therapy in radiation-induced lung injury [14].

\section{Summary}

Although limited data are available for the clinical application of MSCs in radiation-induced normal tissue injury, promising therapeutic benefits have been shown in a small number of isolated clinical studies [29].

Isolated clinical case reports showed promising beneficial effects of MSCs therapy; e.g. regenerating hematopoiesis and osteoradionecrosis, improved breathing parameters and lung immune function, improved intestinal mucosal inflammation, hemorrhages, fistulization, pain and diarrhea, and regenerated skin ulceration, in ionizing radiationinduced injury of bone, lung, intestine, and skin, respectively $[29,40,56,57]$. Table 2 summarizes the recent preclinical and clinical studies conducted in RORM applying MSCs therapies.

\section{Adipose tissue-derived MSCs (aMSCs)}

Adipose tissue-derived mesenchymal stem/stromal cells (aMSCs) are multipotent progenitor cells located in the stromal vascular fraction (SVF) of adipose tissue [2]. They are characterized by expressing cell surface antigens Sca1, CD106, CD105, CD73, CD29, and CD44, and lacking the expression of hematopoietic stem cells (HSCs) surface antigens (e.g. CD11b and CD45) [2,3,58]. In addition to their multilineage differentiation potential, they have anti-inflammatory/ immune-modulatory and paracrine effects [59-61]. In addition, MSCs can home to the site of tissue injury that is caused by irradiation and inflammation [2,5,62].These advantages, in addition to their source abundance, ease of isolation and high cell count after expansion, render aMSCs promising for cellular therapies [63]. Table 3 lists 22 clinical trials using aMSCs therapy for various disorders, with no trial yet found for their application in RORM, following a search on the clinical trials website of the NIH, i.e. https://clinicaltrials.gov/, in Nov. 2015.

\section{MSCs mechanisms of action in RORM}

There are proposed mechanisms of action of MSCs radio-protective properties in radiation-induced normal tissue injury repair. Homing and paracrine effects with anti-inflammatory/immunomodulatory 
Table 3. Adipose Mesenchymal stromal cells (aMSCs) clinical trials www.ClinicalTrials.gov by the national Institute of Health in RORM.

\begin{tabular}{|c|c|c|c|c|}
\hline NCT \# & Title & Conditions & Interventions & Last Verified \\
\hline NCT02603744 & $\begin{array}{c}\text { Autologous Adipose Derived Mesenchymal Stromal Cells } \\
\text { (aMSCs) Transplantation in Women With Premature Ovarian } \\
\text { Failure (POF) }\end{array}$ & Premature Ovarian Failure & Biological: Intraovarian injection of aMSCs & Nov-15 \\
\hline NCT01449032 & $\begin{array}{c}\text { MSCs Therapy in Patients With Chronic Myocardial Ischemia } \\
\text { (MyStromalCell Trial) }\end{array}$ & Chronic Ischemic Heart Disease & Biological: MSCs|Biological: Saline & Jun-14 \\
\hline NCT01585857 & ADIPOA - Clinical Study & Osteoarthritis & $\begin{array}{l}\text { Biological: Autologous aMSCs administrated } \\
\text { for intra-articular use|Biological: Autologous } \\
\text { aMSCs administrated for intra-articular use }\end{array}$ & Dec-14 \\
\hline NCT02382874 & $\begin{array}{l}\text { Allogenic aMSCs Transplantation in Idiopathic Nephrotic } \\
\text { Syndrome (Focal Segmental Glomerulosclerosis) }\end{array}$ & $\begin{array}{l}\text { Focal Segmental } \\
\text { Glomerulosclerosis }\end{array}$ & Biological: Intravenous injection & Mar-15 \\
\hline NCT02240823 & $\begin{array}{l}\text { Can Fat Derived Stem Cells (SVF) be Used in the Treatment of } \\
\text { Erectile Dysfunction After Prostatectomy }\end{array}$ & Delayed Graft Function & Other: aMSCs & Oct-15 \\
\hline NCT02326935 & $\begin{array}{c}\text { Multi-Center Study Safety of aMSCs for the Treatment of } \\
\text { Multiple Sclerosis }\end{array}$ & Multiple Sclerosis & Biological: Autologous aMSCs & Jan-15 \\
\hline NCT00913289 & Liver Regeneration Therapy Using Autologous aMSCs & Liver Cirrhosis & Biological: aMSCs & Oct-12 \\
\hline NCT01062750 & $\begin{array}{c}\text { Liver Regeneration Therapy by Intrahepatic Arterial } \\
\text { Administration of Autologous aMSCs }\end{array}$ & Liver Cirrhosis & Biological: aMSCs dosage & Sep-15 \\
\hline NCT02338271 & Autologous aMSCs Therapy for Intervertebral Disc Degeneration & Low Back Pain & Other: autologous aMSCs & Jan-15 \\
\hline NCT01709279 & $\begin{array}{l}\text { Clinical Trial of Autologous aMSCs Therapy for Ischemic Heart } \\
\text { Failure }\end{array}$ & Ischemic Heart Failure & Biological: aMSCs dosage & Oct-12 \\
\hline NCT01739504 & $\begin{array}{l}\text { Autologous aMSCs Delivered Intra-articularly in Patients With } \\
\text { Osteoarthritis. }\end{array}$ & Osteoarthritis & $\begin{array}{c}\text { Procedure: Autologous aMSCs harvesting } \\
\text { through Liposuction for Intra-articular Injection }\end{array}$ & Oct-15 \\
\hline NCT02145897 & $\begin{array}{c}\text { To Evaluate the Safety and Efficacy of IM and IV Administration } \\
\text { of Autologous aMSCs for Treatment of CLI }\end{array}$ & $\begin{array}{l}\text { Critical Limb Ischemia } \\
\text { (CLI) }\end{array}$ & $\begin{array}{c}\text { Biological: Autologous Stromal Vascular } \\
\text { Fraction (SVF)|Biological: Autologous aMSCs } \mid \\
\text { Other: Control }\end{array}$ & May-14 \\
\hline NCT01840540 & MSC for Occlusive Disease of the Kidney & $\begin{array}{l}\text { Atherosclerot-ic Renal } \\
\text { Artery Stenosis| Ischemic } \\
\text { Nephropathy|Renovascular } \\
\text { Hypertension }\end{array}$ & $\begin{array}{l}\text { Drug: Arterial infusion of autologous } \\
\text { mesenchymal stem cells }\end{array}$ & Oct-15 \\
\hline NCT02135380 & $\begin{array}{l}\text { Evaluate Safety and Efficacy of Intravenous Autologous aMSC } \\
\text { for Treatment of Idiopathic Pulmonary Fibrosis }\end{array}$ & Idiopathic Pulmonary Fibrosis & $\begin{array}{c}\text { Biological: Autologous Stromal Vascular } \\
\text { Fraction (SVF) } \mid \text { Biological: Autologous aMSCs } \\
\mid \text { Other: Control }\end{array}$ & May-14 \\
\hline NCT01548092 & $\begin{array}{l}\text { Stromal Vascular Fraction (SVF) for Treatment of Recto-vaginal } \\
\text { Fistula }\end{array}$ & Recto-vaginal Fistula & Drug: aMSCs without expanded & Mar-12 \\
\hline NCT01771913 & $\begin{array}{l}\text { Immunophenotyping of Fresh Stromal Vascular Fraction From } \\
\text { aMSCs Enriched Fat Grafts }\end{array}$ & $\begin{array}{l}\text { Breast Reconstruction|Contour } \\
\text { Irregularities|Volume } \\
\text { Insufficiency }\end{array}$ & $\begin{array}{l}\text { Genetic: centrifuged fat graft| Genetic: aMSCs } \\
\text { enriched fat graft }\end{array}$ & Jul-15 \\
\hline NCT01849159 & $\begin{array}{c}\text { Clinical Study of the Efficacy and Safety of the Application } \\
\text { of Allogeneic Mesenchymal (Stromal) Cells of Bone Marrow, } \\
\text { Cultured Under the Hypoxia in the Treatment of Patients With } \\
\text { Severe Pulmonary Emphysema }\end{array}$ & Pulmonary Emphysema & $\begin{array}{l}\text { Biological: Mesenchymal stem cells } \mid \text { Other: } \\
\text { Reference therapy: } 400 \mathrm{~mL} \text { of } 0.9 \% \mathrm{NaCl} \\
\text { solution }\end{array}$ & Oct-15 \\
\hline NCT01532076 & $\begin{array}{c}\text { Effectiveness of aMSCs as Osteogenic Component in Composite } \\
\text { Grafts }\end{array}$ & Osteoporotic Fractures & $\begin{array}{l}\text { Procedure: Cellularized composite graft } \\
\text { augmentation|Procedure: Acellular composite } \\
\text { graft augmentation }\end{array}$ & Sep-14 \\
\hline NCT02387723 & CSCC_ASC Therapy in Patients With Severe Heart Failure & $\begin{array}{l}\text { Clinical Patient Safety of } \\
\text { Allogeneic Stem Cell Therapy }\end{array}$ & Biological: Allogeneic aMSCs (CSCC_ASC) & Mar-15 \\
\hline NCT01730547 & Mesenchymal Stem Cells for Multiple Sclerosis & Multiple Sclerosis & Biological: Autologous mesenchymal stem cells & Jan-15 \\
\hline NCT02492490 & Effect of SVF-derived MSC in DCD Renal Transplantation & Uremia & $\begin{array}{c}\text { Other: SVF-derived MSC } \\
\text { transplantations|Drug: Basiliximab }\end{array}$ & Nov-14 \\
\hline NCT02492308 & $\begin{array}{c}\text { Induction With SVF Derived MSC in Living-related Kidney } \\
\text { Transplantation }\end{array}$ & $\begin{array}{l}\text { Living-relative Kidney } \\
\text { Transplantation }\end{array}$ & $\begin{array}{l}\text { Procedure: SVF-MSC induction|Drug: } \\
\text { Basiliximab induction }\end{array}$ & Jul-15 \\
\hline
\end{tabular}

mechanisms are supported by in-vitro data from radiation-induced intestinal injury studies and [59-62]. MSCs therapy in radiationinduced intestinal injury showed the homing of systemically administered MSCs in measurable numbers at the intestinal injury site $[25,26,41]$. There were increased levels of IL-10, VEGF, b-FGF, and EGF. Histopathological studies showed improved intestinal epithelial homeostasis that may be due to MSCs overexpressing stromal cellderived factor receptor CXCR-4 [29]. These findings suggest that the paracrine and the anti-inflammatory effect of MSCs is the expected radio-protective mechanism of action of MSCs in RORM [29].

\section{Challenges facing MSCs therapy}

The fear of MSCs-mediated radioprotection of tumor tissues has been a raised concern after the availability of in-vitro data suggesting that breast cancer cells grow and proliferate more with MSCs-therapy owing to high insulin-like factor production [53]. Also, MSCs have some angiogenic properties evident by increased secretion of platelets derived growth factor (PDGF), VEGF and TGF- $\beta$ at the tumor perivascular area and parenchyma in low dose irradiated mice owing to MSCs infiltration at the tumor site [53]. MSCs angiogenic properties might counteract the anti-angiogenic cancer therapies, a question that needs to be answered with solid in-vitro and in-vivo studies $[28,29]$.

Another challenge appeared in MSCs therapies. MSCs have been found to have heterogeneous radiation resistant populations, both in human and mouse MSCs [53]. A finding that might interfere with the overall radio-protective and tissue regenerative properties of MSCs. 
Nevertheless, studies may find molecular biomarkers for isolating homogenous populations of MSCs with uniform high RT resistance profile $[28,29]$.

A further challenge that has been found to be more frequent in mouse MSCs than in human MSCs, is MSCs in-vitro transformation (the tumorigenic potential of MSCs) [53]. Such challenge carries a significant worry for MSCs therapies, since MSCs are radio-resistant cells. Thus, their transformation may signify the generation of a severe form of radio-resistant tumor that is extremely hard to control. Tight and fine validation of MSCs before each single dose therapy is recommended for preventing the use of any potentially transformed cells $[28,29,34]$.

\section{Conclusion}

MSCs have been widely used in preclinical studies of radiation oncology regenerative medicine. MSCs have been shown to be reliable candidates in radiation oncology regenerative medicine translational and clinical research. The strong potential of MSCs therapy in RIOM is supported by their relative radiation resistance and robust DNA repair mechanisms, multi-lineage differentiation potential, and antiinflammatory/immunomodulatory properties. Nevertheless, few but considerable challenges in MSCs therapies are requiring more research in order to develop solid solutions. However, the overall data collected from preclinical and clinical studies with MSCs therapy promise with cell therapy choices competing the traditional therapies. Adipose-tissue derived mesenchymal stromal/stem cells are reliable candidates for radiation oncology regenerative medicine applications owing to the advantages they possess, e.g. source abundance, enhanced anti-inflammatory effects, robust IL-10 secretion, easy isolation, high expansion.

\section{Authorship and contributions}

Osama Maria: Conception and design, collection and/or assembly of data, review writing, final approval of the review.

Nicoletta Eliopoulos: Conception, design and final approval of the review.

Thierry Muanza: Conception and design, financial support and final approval of the review.

\section{Acknowledgements}

Osama Muhammad Maria is an awardee of the LDI/TD studentship, and Fonds de Récherche du Quebec - Santé (FRQS) doctoral fellowship. This study was supported partially by Ride to Conquer Cancer (RTCC, Jewish General Hospital Foundation) and FRQS grants. This work was partially supported by Canadian Institutes of Health Research (CIHR) Operating Grant MOP-15017 (N. Eliopoulos).

\section{Disclosure of potential conflict of interest}

None.

\section{References}

1. Spitkovsky D, Hescheler J (2008) Adult mesenchymal stromal stem cells for therapeutic applications. Minim Invasive Ther Allied Technol 17: 79-90. [Crossref]

2. Chamberlain, Fox J, Ashton B, Middleton J (2007) Concise review: mesenchymal stem cells: their phenotype, differentiation capacity, immunological features, and potential for homing. Stem Cells 25: 2739-2249. [Crossref]

3. Bianco P, Riminucci M, Gronthos S, Robey PG (2001) Bone marrow stromal stem cells: nature, biology, and potential applications. Stem Cells 19: 180-192. [Crossref]
4. Mouiseddine M, François S, Semont A, Sache A, Allenet B, et al. (2007) Human mesenchymal stem cells home specifically to radiation-injured tissues in a non-obese diabetes/severe combined immunodeficiency mouse model. Br J Radiol 80 Spec No 1: S49-55. [Crossref]

5. Chapel A, Bertho JM, Bensidhoum M, Fouillard L, Young RG, et al. (2003) Mesenchymal stem cells home to injured tissues when co-infused with hematopoietic cells to treat a radiation-induced multi-organ failure syndrome. J Gene Med 5: 10281038. [Crossref]

6. Strem BM, Hicok KC, Zhu M, Wulur I, Alfonso Z, et al. (2005) Multipotential differentiation of adipose tissue-derived stem cells. Keio J Med 54: 132-141. [Crossref]

7. Yi T, Song SU (2012) Immunomodulatory properties of mesenchymal stem cells and their therapeutic applications. Arch Pharm Res 35: 213-221. [Crossref]

8. Shi M, Liu ZW, Wang FS (2011) Immunomodulatory properties and therapeutic application of mesenchymal stem cells. Clin Exp Immunol 164: 1-8. [Crossref]

9. Marigo I, Dazzi F (2011) The immunomodulatory properties of mesenchymal stem cells. Semin Immunopathol 33: 593-602. [Crossref]

10. Doorn J, Moll G, Le Blanc K, van Blitterswijk C, de Boer J (2012) Therapeutic applications of mesenchymal stromal cells: paracrine effects and potential improvements. Tissue Eng Part B Rev 18: 101-115. [Crossref]

11. Moura JF, Mota JM, Leite CA, Wong DV, Bezerra NP, et al. (2015) A novel model of megavoltage radiation-induced oral mucositis in hamsters: Role of inflammatory cytokines and nitric oxide. Int J Radiat Biol 91: 500-509. [Crossref]

12. Wang H, Sun RT, Li Y, Yang YF, Xiao FJ, et al. (2015) HGF Gene Modification in Mesenchymal Stem Cells Reduces Radiation-Induced Intestinal Injury by Modulating Immunity. PLoS One 10: e0124420. [Crossref]

13. Zhang J, Zhou S, Zhou Y, Feng F, Wang Q, et al. (2014) Hepatocyte growth factor genemodified adipose-derived mesenchymal stem cells ameliorate radiation induced liver damage in a rat model. PLoS One 9: e114670. [Crossref]

14. Xue J, Li X, Lu Y, Gan L, Zhou L, et al. (2013) Gene-modified mesenchymal stem cells protect against radiation-induced lung injury. Mol Ther 21: 456-465. [Crossref]

15. Galindo LT, Semedo P, Ariza CB, Moreira CM, Camara NOS, et al. (2011) Mesenchymal Stem Cell TherapyModulates the Inflammatory Response in Experimental Traumatic Brain Injury. Neurol Res Int 2011: 1-9.

16. Bouffi C, Djouad F, Mathieu M, Noël D, Jorgensen C (2009) Multipotent mesenchymal stromal cells and rheumatoid arthritis: risk or benefit? Rheumatology (Oxford) 48: 1185-1189. [Crossref]

17. Mathur A, Martin JF (2004) Stem cells and repair of the heart. Lancet 364: 183-192. [Crossref]

18. Orlic D, Kajstura J, Chimenti S, Limana F, Jakoniuk I, et al. (2001) Mobilized bone marrow cells repair the infarcted heart, improving function and survival. Proc Natl Acad Sci U S A 98: 10344-10349. [Crossref]

19. Ezquer FE, Ezquer ME, Parrau DB, Carpio D, Yañez AJ, et al. (2008) Systemic administration of multipotent mesenchymal stromal cells reverts hyperglycemia and prevents nephropathy in type 1 diabetic mice. Biol Blood Marrow Transplant 14: 631640. [Crossref]

20. Riccobono D, Agay D, Scherthan H, Forcheron F, Vivier M, et al. (2012) Application of adipocyte-derived stem cells in treatment of cutaneous radiation syndrome. Health Phys 103: 120-126. [Crossref]

21. Kotenko KB, Moroz BB, Nadezhina NM, Galstian IA, Onishchenko NA, et al. (2011) [Mesenchymal stem cells transplantation in the treatment of radiation skin lesions] Patol Fiziol Eksp Ter: 20-25. [Crossref]

22. Bargues L, Prat M, Leclerc T, Bey E, Lataillade JJ (2011) [Present and future of cell therapy in burns]. Pathol Biol (Paris) 59: e49-56. [Crossref]

23. Jeong JH (2010) Adipose stem cells and skin repair. Curr Stem Cell Res Ther 5: 137140. [Crossref]

24. Arthur A, Zannettino A, Gronthos S (2009) The therapeutic applications of multipotential mesenchymal/stromal stem cells in skeletal tissue repair. $J$ Cell Physiol 218: 237-245. [Crossref]

25. Kudo K, Liu Y, Takahashi K, Tarusawa K, Osanai M, et al. (2010) Transplantation of mesenchymal stem cells to prevent radiation-induced intestinal injury in mice. J Radiat Res 51: 73-79. [Crossref]

26. Sémont A, François S, Mouiseddine M, François A, Saché A, et al. (2006) Mesenchymal stem cells increase self-renewal of small intestinal epithelium and accelerate structural 
recovery after radiation injury. Adv Exp Med Biol 585: 19-30. [Crossref]

27. Sugrue T, Lowndes NF, Ceredig R (2013) Mesenchymal stromal cells: radio-resistant members of the bone marrow. Immunol Cell Biol 91: 5-11. [Crossref]

28. Nicolay NH, Lopez Perez R,, et al. (2015) Radio-resistant mesenchymal stem cells: mechanisms of resistance and potential implications for the clinic. Oncotarget 6: 19366-19380. [Crossref]

29. Nicolay NH, Lopez Perez R, Debus J, Huber PE4 (2015) Mesenchymal stem cells. A new hope for radiotherapy-induced tissue damage? Cancer Lett 366: 133-140. [Crossref]

30. Chen MF, Lin CT, Chen WC, Yang CT, Chen CC, et al. (2006) The sensitivity of human mesenchymal stem cells to ionizing radiation. Int J Radiat Oncol Biol Phys 66: 244253. [Crossref]

31. Maria OM, Kumala S, Heravi M, Syme A4, Eliopoulos N5, et al. (2016) Adipose mesenchymal stromal cells response to ionizing radiation. Cytotherapy 18: 384-401. [Crossref]

32. Oliver L, Hue E, Séry Q, Lafargue A, Pecqueur C, et al. (2013) Differentiation-related response to DNA breaks in human mesenchymal stem cells. Stem Cells 31: 800-807. [Crossref]

33. Prendergast ÁM, Cruet-Hennequart S, Shaw G, Barry FP, Carty MP (2011) Activation of DNA damage response pathways in human mesenchymal stem cells exposed to cisplatin or gamma-irradiation. Cell Cycle 10: 3768-3777. [Crossref]

34. Frosina G (2010) The bright and the dark sides of DNA repair in stem cells. J Biomed Biotechnol 2010: 845396. [Crossref]

35. De Lorenzo SB, Patel AG, Hurley RM, Kaufmann SH (2013) The elephant and the blind men: making sense of PARP inhibitors in homologous recombination deficient tumor cells. Front Oncol 3: 228. [Crossref]

36. Horton JA, Hudak KE, Chung EJ, White AO, Scroggins BT, et al. (2013) Mesenchymal stem cells inhibit cutaneous radiation-induced fibrosis by suppressing chronic inflammation. Stem Cells 31: 2231-2241. [Crossref]

37. Kim WS, Park BS, Sung JH (2009) Protective role of adipose-derived stem cells and their soluble factors in photoaging. Arch Dermatol Res 301: 329-336. [Crossref]

38. Zhang J, Gong JF, Zhang W, Zhu WM, Li JS (2008) Effects of transplanted bone marrow mesenchymal stem cells on the irradiated intestine of mice. J Biomed Sci 15: 585-594. [Crossref]

39. Chang P, Qu Y, Liu Y, Cui S, Zhu D, et al. (2013) Multi-therapeutic effects of human adipose-derived mesenchymal stem cells on radiation-induced intestinal injury. Cell Death Dis 4: e685.

40. Bessout R, Sémont A, Demarquay C, Charcosset A, Benderitter M, et al. (2014) Mesenchymal stem cell therapy induces glucocorticoid synthesis in colonic mucosa and suppresses radiation-activated T cells: new insights into MSC immunomodulation. Mucosal Immunol 7: 656-669. [Crossref]

41. Chen H, Min XH, Wang QY, Leung FW, Shi L5, et al. (2015) Pre-activation of mesenchymal stem cells with TNF- $\alpha$, IL- $1 \beta$ and nitric oxide enhances its paracrine effects on radiation-induced intestinal injury. Sci Rep 5: 8718. [Crossref]

42. Jiang X, Jiang X, Qu C, Chang P, Zhang C, et al. (2015) Intravenous delivery of adipose-derived mesenchymal stromal cells attenuates acute radiation-induced lung injury in rats. Cytotherapy 17: 560-570. [Crossref]

43. Klein D, Schmetter A, Imsak R, Wirsdörfer F, Unger K, et al. (2015) Therapy with multipotent mesenchymal stromal cells protects lungs from radiation-induced injury and reduces the risk of lung metastasis. Antioxid Redox Signal 24: 53-69. [Crossref]

44. Kursova LV, Konoplyannikov AG, Pasov VV, Ivanova IN, Poluektova MV, et al. (2009) Possibilities for the use of autologous mesenchymal stem cells in the therapy of radiation-induced lung injuries. Bull Exp Biol Med 147: 542-546. [Crossref]

45. Wang R, Zhu CZ, Qiao P, Liu J, Zhao Q, et al. (2014) Experimental treatment of radiation pneumonitis with human umbilical cord mesenchymal stem cells. Asian Pac J Trop Med 7: 262-266. [Crossref]

46. Zhang J, Zhou S, Zhou Y, Feng F, Wang Q, et al. (2015) Adipose-derived Mesenchymal Stem Cells (ADSCs) with the Potential to Ameliorate Platelet Recovery, Enhance Megakaryopoiesis and Inhibit Apoptosis of Bone Marrow Cells in a Mouse Model of Radiation-Induced Thrombocytopenia. Cell Transplant 25: 261-273. [Crossref]

47. Drouet M, Mourcin F, Grenier N, Delaunay C, Mayol JF, et al. (2005) Mesenchymal stem cells rescue CD34+ cells from radiation-induced apoptosis and sustain hematopoietic reconstitution after coculture and cografting in lethally irradiated baboons: is autologous stem cell therapy in nuclear accident settings hype or reality?
Bone Marrow Transplant 35: 1201-1209. [Crossref]

48. Gan J, Meng F, Zhou X, Li C, He Y, et al. (2015) Hematopoietic recovery of acute radiation syndrome by human superoxide dismutase-expressing umbilical cord mesenchymal stromal cells. Cytotherapy 17: 403-417. [Crossref]

49. Kursova LV, Konoplyannikov AG, Kal'sina SSh, Baboyan SB (2014) Allogenic cardiomyoblasts raised from human mesenchymal stem cells in the therapy of radiation cardiomyopathy and pericarditis: case report. Bull Exp Biol Med 157: 143-145. [Crossref]

50. Lim JY, Ra JC, Shin IS, Jang YH, An HY, et al. (2013) Systemic transplantation of human adipose tissue-derived mesenchymal stem cells for the regeneration of irradiation-induced salivary gland damage. PLoS One 8: e71167. [Crossref]

51. Schmidt M, Haagen J, Noack R, Siegemund A, Gabriel P, et al. (2013) Effects of bone marrow or mesenchymal stem cell transplantation on oral mucositis (mouse) induced by fractionated irradiation. Strahlenther Onkol 4: 399-404. [Crossref]

52. Schmidt M, Haagen J, Noack R, Siegemund A, Gabriel P, et al. (2014) Effects of bone marrow or mesenchymal stem cell transplantation on oral mucositis (mouse) induced by fractionated irradiation. Strahlenther Onkol 190: 399-404. [Crossref]

53. Schmidt M, Piro-Hussong A, Siegemund A, Gabriel P, Dörr W (2014) Modification of radiation-induced oral mucositis (mouse) by adult stem cell therapy: single-dose irradiation. Radiat Environ Biophys 53: 629-634. [Crossref]

54. Francois S, Mouiseddine M, Allenet-Lepage B, Voswinkel J, Douay L, et al. (2013) Human mesenchymal stem cells provide protection against radiation-induced liver injury by antioxidative process, vasculature protection, hepatocyte differentiation, and trophic effects. Biomed Res Int 2013: 151679.

55. Chen YX, Zeng ZC, Sun J, Zeng HY, Huang Y, et al. (2015) Mesenchymal stem cellconditioned medium prevents radiation-induced liver injury by inhibiting inflammation and protecting sinusoidal endothelial cells. $J$ Radiat Res 56: 700-708. [Crossref]

56. Voswinkel J, Francois S, Gorin NC, Chapel A (2013) Gastro-intestinal autoimmunity: preclinical experiences and successful therapy of fistulizing bowel diseases and gut Graft versus host disease by mesenchymal stromal cells. Immunol Res 56: 241-248. [Crossref]

57. Benderitter M, Caviggioli F, Chapel A, Coppes RP, Guha C, et al. (2014) Stem cell therapies for the treatment of radiation-induced normal tissue side effects. Antioxid Redox Signal 21: 338-355. [Crossref]

58. Baer PC, Geiger H (2012) Adipose-derived mesenchymal stromal/stem cells: tissue localization, characterization, and heterogeneity. Stem Cells Int 2012: 812693. [Crossref]

59. Schwerk A, Altschüler J, Roch M, Gossen M, Winter C, et al. (2015) Adipose-derived human mesenchymal stem cells induce long-term neurogenic and anti-inflammatory effects and improve cognitive but not motor performance in a rat model of Parkinson's disease. Regen Med 10: 431-446. [Crossref]

60. Mert T, Kurt AH, Arslan M, Çelik A, Tugtag B, et al. (2015) Anti-inflammatory and Anti-nociceptive Actions of Systemically or Locally Treated Adipose-Derived Mesenchymal Stem Cells in Experimental Inflammatory Model. Inflammation 38: 1302-1310. [Crossref]

61. Kim Y, Jo SH, Kim WH, Kweon OK4 (2015) Antioxidant and anti-inflammatory effects of intravenously injected adipose derived mesenchymal stem cells in dogs with acute spinal cord injury. Stem Cell Res Ther 6: 229. [Crossref]

62. François S, Bensidhoum M, Mouiseddine M, Mazurier C, Allenet B, et al. (2006) Loca irradiation not only induces homing of human mesenchymal stem cells at exposed sites but promotes their widespread engraftment to multiple organs: a study of their quantitative distribution after irradiation damage. Stem Cells 24: 1020-1209. [Crossref]

63. Brooke G, Cook M, Blair C, Han R, Heazlewood C, et al. (2007) Therapeutic applications of mesenchymal stromal cells. Semin Cell Dev Biol 18: 846-858. [Crossref]

Copyright: (C2016 Maria OM. This is an open-access article distributed under the terms of the Creative Commons Attribution License, which permits unrestricted use, distribution, and reproduction in any medium, provided the original author and source are credited. 